\title{
Investigation and Thinking on the Middle-elementary School Teachers-training with Case-study
}

\author{
Hong-Guang HA, Xiao-Ping XIANG \\ Department of Foreign Languages, Ankang University, Ankang, Shanxi, 725000, China \\ yyx7727@126.com
}

Keywords: Middle-primer school teachers, Education and training, Investigation, Analysis, Proposal.

\begin{abstract}
To have a proper probe into the current situation of teachers training in Ankang, with the help of the theories of pedagogy in teaching, we made a research into the training process and had the statistics in the training. When the detailed analyses are done, we put forward the new ideas and some strategies in the future training.
\end{abstract}

\section{Introduction}

Ankang Area is in the southern part of Qinling Maintain, which belongs to the under-developed regions in China. The situation of the education is relatively poor. So, the teacher-education and teacher-training of elementary and middle schools are in need strongly. In order to solve the problem theoretically, we made an investigation into the field, aiming to understand further the current situation of teacher-education and teacher-training, and to find out the problems in the field. In the end we hope to find out the solutions and strategies to solve the problems by analyzing the data that collected in the investigations.

\section{The Design of Investigation}

In order to have a general idea of how on going the English teacher training in primary and middle schools in Ankang, the research group arranged an investigation into the schools, of which, there are four middle-schools in the urban area, five middle-elementary ones located in the counties, and three elementary schools located in the Township. The aim of it is to know how the Summer Training Program going on last year. The investigation is made with interviewing, phone-call, and questionnaire. What we want to know is the present situation of English teachers in the schools and how many of them have attended the training, and what has been learnt in the program. There are totally 585questionnaires sent out to the teachers, and the reclaimed questionnaire is 532. The investigated objects are classified into the high schools, junior high schools and primary school. The total number of the objects is 189 English teachers in senior high schools, 296 are in junior high school, and 47 in elementary schools. If the investigation is arranged geographically, the schools can be divided into urban schools and rural schools in two categories, among which there are 189 teachers working in urban area and 343 teachers working in rural area. If the teachers are classified with education background, there are 331 of them with four-year certificates and bachelor degree, and 205 of them with college-degree or with under college-degree. If the teachers are grouped with academic titles, there are 51 with senior professional ranks, 191 with intermediate ranks and 290 of them with junior professional ranks. The ages of them are within the range of 25-53, 398 of them are under 40 years old; 106 of them at the age of 40-50, and 28 of them are over 50 years old.

\section{Investigation and Analysis}

The following were the survey of current situation of English teachers training results of the middle and primary school teachers in Ankang area, which need our further interpretation and analysis. 
The results of the investigation of present situation of the English teachers in primary and secondary schools in Ankang area.

Table-1 Survey of the situation of English teachers in primary and middle school in Ankang area (\%)

\begin{tabular}{|l|l|l|l|l|l|l|l|l|l|l|l|}
\hline \multirow{2}{*}{ Category } & \multicolumn{2}{|l|}{ gender(\%) } & \multicolumn{2}{l|}{ age(\%) } & \multicolumn{2}{l|}{ degree(\%) } & \multicolumn{2}{l|}{ Professional rank(\%) } & \multicolumn{2}{l|}{ major(\%) } \\
\cline { 2 - 12 } & female & male & $20-40$ & $41-50$ & $\begin{array}{l}\text { Under- } \\
\text { graduate }\end{array}$ & $\begin{array}{l}\text { College } \\
\text { degree }\end{array}$ & senior & $\begin{array}{l}\text { Inter- } \\
\text { mediate }\end{array}$ & $\begin{array}{l}\text { junio } \\
\text { r }\end{array}$ & English & other \\
\hline $\begin{array}{l}\text { High } \\
\text { school }\end{array}$ & 73.3 & 26.7 & 72.8 & 27.2 & 95 & 3 & 16.2 & 35.2 & 48.6 & 100 & 0 \\
\hline $\begin{array}{l}\text { junior } \\
\text { middle } \\
\text { school }\end{array}$ & 76.8 & 23.2 & 78.3 & 21.7 & 85.2 & 14.8 & 5.2 & 25.3 & 69.5 & 100 & 0 \\
\hline $\begin{array}{l}\text { Primary } \\
\text { school }\end{array}$ & 89.5 & 10.5 & 90.8 & 9.2 & 82.6 & 17.3 & 0 & 14.2 & 85.8 & 98 & 2 \\
\hline \begin{tabular}{l} 
Urban \\
\hline f8.2
\end{tabular} & 22.8 & 74.6 & 25.4 & 91.3 & 8.7 & 18.5 & 36.3 & 45.2 & 100 & 0 \\
\hline rural & 70.6 & 29.4 & 78.9 & 21.1 & 72.5 & 27.5 & 6.5 & 27 & 66.5 & 94 & 6 \\
\hline
\end{tabular}

Table-1 is the reflection of the current situation of English teachers in primary and middle schools in Ankang. The data of the Table-1 shows, at present, the English teachers, no matter in primary or middle schools are better qualified in the urban area, than those working in the rural schools. The teachers working in high schools are obviously powerful than those staying in junior high schools and elementary schools. In terms of gender, the female teachers take a lion share in the proportion (78.2\%). If judging from the age, the teachers of the senior level and experiences, make up of the main parts of the proportion $(78.9 \%-74.6 \%)$ than the young teachers. If making the academic background as a point of view, the teachers, with bachelor degree or above, account for the largest proportion (about 85.3\%). Only about $14.7 \%$ of the teachers graduated with English college-degree, which proved that the teachers' academic standard meets the demands required by the governments. Judged from the point of professional title distribution, the teachers staying in the urban area are stronger than those staying in the countryside. However, the teachers with high rank are less than the general proportion of intermediate level and low level ones. The questionnaire also shows that teachers of English majors are of much higher proportion (about 99\%), only a few teachers, graduated from other majors, take English courses in rural schools. So, the teaching quality of this sort is inevitably to be affected. This kind of phenomenon needs our much concern.

\section{Survey of the teaching and research of the teachers in Ankang (\%)}

When making a study of the data, we can find the results that the working hours of English teachers do not vary much in different categories of school. But in the fields of academic performance and teaching reflections, there exist the differences that the teachers in senior high school performed much better than those in junior high school; and teachers in junior high did much better than those in primary school. The teachers in urban area carried out better than those in rural area. The teachers working within 10 hours account for $18 \%$, while those working at 10-20 hours account for 82\%. The English teachers undertake much work and much pressure. Most of teachers declared that more working hours make them feel too exhausted to make further progress in teaching. Compared with teachings, the academic research proved poor. Much pressure in teaching leaves no time for them to perform the research, which should be paid attention to by the administrators at different levels. How to stimulate the enthusiasm of the teachers, and how to improve the circumstances of academy may be a better way to help them of the dilemma. As to teaching reflection, the teachers did much less than other alternatives, which need down to earth actions in the future.

Table 2 shows the current situations of the teachings and researches done by English teachers of all levels. 
Table-2 shows the present situations of the teaching and academic capacities (\%)

\begin{tabular}{|c|c|c|c|c|c|c|c|c|c|c|}
\hline \multirow[t]{2}{*}{$\begin{array}{l}\text { Categ } \\
\text { ory }\end{array}$} & \multicolumn{2}{|c|}{$\begin{array}{l}\text { Working } \\
\text { Hour Per } \\
\text { Week }\end{array}$} & \multicolumn{4}{|c|}{ Teaching } & \multicolumn{2}{|c|}{$\begin{array}{l}\text { Academic } \\
\text { capabilities }\end{array}$} & \multicolumn{2}{|c|}{$\begin{array}{l}\text { Teaching } \\
\text { Reflections }\end{array}$} \\
\hline & $\begin{array}{l}\text { 10hs- } \\
\text { Plus }\end{array}$ & $\begin{array}{l}\text { 10hs } \\
- \\
\text { Minu } \\
\text { S }\end{array}$ & $\mathrm{t}^{\mathrm{Tes}}$ & $\begin{array}{l}\text { Text- } \\
\text { book }\end{array}$ & $\begin{array}{l}\text { Teachi } \\
\text { ng } \\
\text { Metho } \\
\text { d }\end{array}$ & $\begin{array}{l}\text { Teach } \\
\text { ing-id } \\
\text { eas }\end{array}$ & $\begin{array}{l}\text { Publ } \\
\text { ishe } \\
\text { d }\end{array}$ & $\begin{array}{l}\text { Not } \\
\text { Publish } \\
\text { ed }\end{array}$ & $\begin{array}{l}\text { Self-re } \\
\text { flectio } \\
n\end{array}$ & $\begin{array}{l}\text { Alternat } \\
\text { ives }\end{array}$ \\
\hline $\begin{array}{l}\text { Senior } \\
\text { High }\end{array}$ & 87.1 & 12.9 & 61.5 & 18.2 & 8.1 & 12.2 & 70.6 & 29.4 & 45.3 & 54.7 \\
\hline $\begin{array}{l}\text { Junior } \\
\text { High }\end{array}$ & 86.2 & 13.8 & 57.6 & 16.5 & 10.5 & 15.4 & 63.7 & 36.3 & 42.1 & 57.9 \\
\hline $\begin{array}{l}\text { primar } \\
\mathrm{y}\end{array}$ & 75.3 & 24.7 & 21.3 & 46.5 & 18.6 & 13.6 & 48.3 & 51.7 & 40.6 & 59.4 \\
\hline Urban & 81.8. & 18.2 & 57.4 & 21.3 & 8.1 & 13.2 & 69.8 & 30.2 & 46.3 & 53.7 \\
\hline Rural & 83.2 & 16.8 & 62.4 & 16.9 & 9.1 & 11.6 & 46.5 & 53.5 & 41.2 & 58.8 \\
\hline
\end{tabular}

\subsection{Survey of Teachers of the area in Training $(\%)$}

Table 3 teachers involved in different training (\%)

\begin{tabular}{|l|l|l|l|l|l|l|l|l|l|l|}
\hline $\begin{array}{l}\text { Cate } \\
\text { gory }\end{array}$ & $\begin{array}{l}\text { Educati } \\
\text { onal } \\
\text { Compe } \\
\text { nsation }\end{array}$ & $\begin{array}{l}\text { Dista } \\
\text { nce } \\
\text { Educ } \\
\text { ation }\end{array}$ & $\begin{array}{l}\text { Teac } \\
\text { h } \\
\text { ing } \\
\text { Rese } \\
\text { arch }\end{array}$ & $\begin{array}{l}\text { Spot } \\
\text { Trai } \\
\text { n- } \\
\text { ing }\end{array}$ & $\begin{array}{l}\text { Inter } \\
\text {-scho } \\
\text { ol } \\
\text { Exch } \\
\text { ange }\end{array}$ & $\begin{array}{l}\text { Invited } \\
\text { Expert } \\
\text { s }\end{array}$ & $\begin{array}{l}\text { Teachi } \\
\text { ng } \\
\text { Observ } \\
\text { ation }\end{array}$ & $\begin{array}{l}\text { Teac } \\
\text { hing } \\
\text { Lect } \\
\text { ures }\end{array}$ & $\begin{array}{l}\text { Self-re } \\
\text { fle-ctio } \\
\mathrm{n}\end{array}$ & $\begin{array}{l}\text { Other } \\
\text { Altern- } \\
\text { ative }\end{array}$ \\
\hline $\begin{array}{l}\text { Seni } \\
\text { or } \\
\text { High }\end{array}$ & 72.3 & 43.2 & 74.6 & 58.3 & 62.6 & 34.6 & 69.1 & 63.2 & 47.3 & 4.2 \\
\hline $\begin{array}{l}\text { Juni } \\
\text { or } \\
\text { High }\end{array}$ & 68.7 & 34.5 & 62.1 & 41.2 & 58.7 & 29.8 & 65.9 & 71.1 & 43.1 & 6.4 \\
\hline $\begin{array}{l}\text { prim } \\
\text { ary }\end{array}$ & 44.6 & 26.4 & 45.2 & 39.8 & 59.5 & 32.1 & 76.5 & 67.3 & 40.6 & 2.1 \\
\hline $\begin{array}{l}\text { Urba } \\
\text { n }\end{array}$ & 61.2 & 35.6 & 70.2 & 52.9 & 58.6 & 45.3 & 78.1 & 68.1 & 46.3 & 4.9 \\
\hline $\begin{array}{l}\text { Rura } \\
1\end{array}$ & 65.8 & 15.8 & 61.8 & 46.1 & 61.2 & 28.6 & 64.9 & 64.2 & 41.2 & 2.6 \\
\hline
\end{tabular}

Table 3 shows the current situations of teacher training of the English teachers in Ankang area. The concluded data proved that "Teaching Seminar" and "Spot Presentation" have become the major means in the new-concept-based English teacher training or self-education. When going down to the local schools, we may find In teaching practice, the teaching observation and teaching contest are the important channels to improve teaching abilities of English teachers. Teaching research and presentation in teaching have been regarded as the usual path to perform self-promotion for all middle school teachers. Education compensation can still win favor from the teachers working in rural schools. The teachers of the investigated schools are coming to take up the means of Self-reflective teaching. And the teachers are inclined to favor the methods of face-to-face guidance made by experts from outside world.

\section{Counter-measures and proposals}

The project can be carried out by the training-institutions in Ankang, and the organizations belong to provincial mechanism. Firstly, a long-term training project is needed that can ensure the training focusing 
on theoretical training in pedagogic, psychology, methodology, and modern technology (CAI). But this is not enough; we have to put the theories into practice, to solve the specific problems with specific measures. In the training, we ought to bring the contemporary educational theories and methods into the lectures, to tell the trainees how to apply the up-to-date theories into the everyday teaching affairs. In particular, the emphasis on the introduction and application of new teaching theories can help promote the new curriculum design and seminar of new teaching notions. Thirdly, some sample schools can be selected to undertake the face-face teaching training practice and guidance through heart-felt spot presentation and review in time. When the plan is carried out, the location, timing and content of effect-oriented training project have to be taken into consideration. We have to balance the activities in theories and practice, observation and evaluation, etc.

The training of teachers at different levels is a sophisticated work, but how to make it on going well will leave us a hard job only guaranteed by rational systems. So, to establish solid systems and perfect the management mechanism [1] before the teacher training is real in need indeed. The administrative department of education is in the leading position in middle school English teacher education and training. They are supposed to set up inspection teams at different levels such as in the city and rural areas, to offer help to the different stations for training. The teams should go out to the local training schools for supervision and guidance. The schools chosen as the training stations ought to take the very important responsibility of education and training. The schools should make the device to actively plan and organize a good education and training [2]. In the training process, we should start from the system construction, set up a leading and working mechanism, develop training plans, perfecting the training system, and improve training files. The specified management education institutions of teacher training will continue to pay attention to the development of the new curriculum reform, formulate effective measures, to increase appropriately capital investment, to help the in-service teachers to go on the academic and non academic training by self training. The staff in the training schools should constantly bring the trainees into the field of academics to study further the realistic problems in the daily teaching. The mechanism of evaluation, incentiveness and restraintness has to be established to have the training to go smoothly. Some special funds for education and training have to be raised; some relevant policies and regulations have to be set up so as to perfect the [3] support system of education and training which will be, of course, sustainable. At the same time, the training process and results of the trainees will be taken into the annual assessment, annual recruitment and professional rank assessment, In order to make teachers give full play to their work.

According to the survey, we can conclude that in the aspect of English teachers' education and training for the primary and secondary school in Ankang region, four things should be emphasized: updating the theoretical knowledge, changing the teaching methodology, improving teaching skills and researching the education and teaching. Among these the updating of theoretical knowledge contains three levels, namely: the basic education theory, English learning theory and teaching theory. Educational theory covers the theory of pedagogy, education psychology and teachers' psychology, etc; English learning theory includes the second language acquisition, learning psychology, learning styles and learning strategies [4]. English teaching theory includes English teaching strategies, classroom assessment, language ability testing, language skills improving, etc; the transformation of teaching methodology can be achieved by setting up courses of teacher's professional ethics and the second language acquisition theory for new teachers and by guiding the trainees to change their transitional concept and establish new concept of teaching; The training on teaching skills refer to the practice of modern education technologies and trial teaching practice. Regarding the improvement of modern education technologies, computer operation, making courseware, setting up web pages, collecting materials, etc are the primary approaches; Trial teaching mainly makes use of classroom teaching cases to train and guide new teachers on site to practice teaching skills in real class teaching. Educating and teaching research is aimed at training teachers to analyze problems existed in teaching practice in order to gain the ability to solve the problems. The training teachers should participate in and guide the trainee teachers to raise questions in teaching practice and reflect on them, and jointly probe and solve these problems.

To ensure a good training effect, we must pay special attention to one thing, that is, the establishment of a multiple evaluation system. As is known to all, education and training is a passive process for educatees. As a famous saying in British education circle, "no skill training, no salary promotion". In other words, 
for the teachers' training in Ankang region, the effect is depended on whether we can establish a pertinent training evaluation, whether the evaluation system is incentive oriented and quality monitoring and whether the evaluation on training effectiveness is objective and fair. Whether all these problems can be properly solved can directly affect the quality of our training [5]. Broadly speaking, we should bring in the well-known evaluation pattern: "process plus result", "qualitative and quantitative". In fact, the core of the issue here is that we should bring trainees' performances in their training process under the evaluation system. Our training is not a brief introduction of the theoretical knowledge and practical skills, but a process that requires joint efforts of trainers and trainees. Otherwise, we would back to the old practice of solely imparting knowledge in secondary schools. Now, we focus on whether teachers' teaching methodology can be renewed through training, whether the teaching skills acquired through training can solve problems in real teaching, and whether trainees' abilities of analyzing problems, researching problems and solving problems are really improved. When implementing the quantitative evaluation, it should be combined with the qualitative evaluation. This can be realized by combining trainees' mutual assessment with the teachers' overall assessment, and on this basis, assessing the trainees' grade. At the end of the training, when issuing the completion certificate to the trainees, trainees' attendance, class discussion and course paper should be strictly taken into consideration in order to achieve an overall assessment and ensure the objectivity and impartiality of the assessment.

The teacher training of primary and secondary school is an important measure to improve the English teaching, and the training is also one of the most important goals. In this sense, how to improve the English teachers' training of primary and secondary school has been the key to upgrading their competence. As mentioned in On Accelerating Another Overall Teacher Training of Primary and Secondary Schools, a highly competent teacher faculty is the fundamental element of qualified education resources and the pivotal to the development of education [6]. In view of these, we started this research project and conducted an overall survey on teacher's training in Ankang City. This article sets forth a series of viewpoints, aiming to serve the training work of English teachers from primary and secondary schools.

\section{References}

[1] Zhong Qiquan, The Essential of Teacher Training for New Courses.Beijing: Peking University Press, 2002.

[2] Li Yinfang, A Research on the Professional Development of Qualified Secondary school English Teacher: after 2010. English Teaching and Research in Normal Colleges and Universities, 3rd Issue, 2009, pp5-7.

[3] Department of Teacher Education of Ministry of Education, Theories and Practices on the Profession of Teacher. Beijing: People's Education Press, 2003.

[4] Shu Dingfang, Zhuang Zhixiang, Modern Foreign Languages Teaching: Theories, Practices and Methods. Shanghai: Shanghai Foreign Languages Education Press, 1996.

[5] Zhong Qiquan, The Essential of Teacher Training for New Courses.Beijing: Peking University Press, 2002.

[6] Tu Henghan, Evaluation on Innovative Education. Shanghai: Oriental Education Press, 2001. 